Jurnal Indonesia Sosial Teknologi: p-ISSN: 2723 - 6609

e-ISSN : 2745-5254

Vol. 2, No. 6 Juni 2021

\title{
PERAN DESAIN KEMASAN INDOMIE EDISI RAMADHAN 2021 TERHADAP NILAI SAHAM PT. INDOFOOD SUKSES MAKMUR TBK. PERIODE FEBRUARI S/D APRIL 2021
}

\author{
Muhammad Ilham Kurniawan, Popo Subroto, Maryana, Syahrial Shaddiq, dan \\ Muhammad Zainul \\ Universitas Islam Kalimantan Muhammad Arsyad Al Banjari Banjarmasin \\ Email: ilhamkurniawan.3954@gmail.com, poposubrata@gmail.com, \\ ana.marianakpi@gmail.com syahrial.shaddiq@mail.ugm.ac.id, \\ zainul38@yahoo.co.id,
}

\begin{abstract}
Indonesia is a country with a wealth of natural resources, culture, ethnicity, nation, language as well as the largest seasonally populated country in the world. Islam is a religion that has been perfected by the sending of the Prophet as the last prophet. Every religion certainly has teachings that must be carried out by its adherents. Among the teachings of Islam that must be implemented for every Muslim who is able to do it is fasting in the month of Ramadan. Bulan Ramadhan was welcomed by every line of life in Indonesia, including instant noodle producer PT. Indofood Sukses Makmur Tbk .. By issuing the Ramadhan edition packaging design, will the design affect the value of the company's shares, it is interesting to examine the problem formulation: How is the Role of Indomie Packaging Design Ramadhan Edition 2021 on the Share Value of PT. Indofood Sukses Makmur Tbk. Period February s / d April 2021. Research objectives: To find out how the Role of Indomie Packaging Design Ramadhan Edition 2021 Against the Share Value of PT. Indofood Sukses Makmur Tbk. Period February to April 2021. Using qualitative approaches and descriptive analysis, this study focuses on analyzing or interpreting written material based on its context. Data taken from observation. The results of the analysis found that good quality products that are able to read consumer desires with the support of attractive packaging designs along with the right marketing techniques are able to generate profits for companies with effective, efficient businesses that have a positive effect on all lines of the company.
\end{abstract}

Keywords: communication; managemet advertising; instan noodle.

\begin{abstract}
Abstrak
Indonesia negara dengan kekayaan sumber daya alam, budaya, suku, bangsa bahasa serta negara berpenduduk Musim terbesar di dunia. Islam merupakan agama telah disempurnakan dengan diutusnya Rasulullah sebagai nabi terakhir. Setiap agama tentu memiliki ajaran yang wajib dilaksanakan oleh penganutnya. Diantara ajaran agama Islam yang wajib dilaksanakan bagi tiap muslim yang mampu melaksanakannya adalah puasa di bulan Ramadhan. Bulan Ramadhan disambut baik oleh setiap lini kehidupan di Indonesia termasuk produsen mie instan PT. Indofood Sukses Makmur Tbk.. Dengan mengeluarkan desain kemasan edisi Ramadhan,
\end{abstract}


akankah desain tersebut berpengaruh dengan nilai saham perusahaan tersebut, ini menarik diteliti dengan rumusan masalah: Bagaimana Peran Desain Kemasan Indomie Edisi Ramadhan 2021 Terhadap Nilai Saham PT. Indofood Sukses Makmur Tbk. Periode Februari s/d April 2021. Tujuan penelitian: Untuk mengetahui bagaimana Peran Desain Kemasan Indomie Edisi Ramadhan 2021 Terhadap Nilai Saham PT. Indofood Sukses Makmur Tbk. Periode Februari s/d April 2021. Menggunakan pendekatan kualitatif dan analisis deskriptif, penelitian ini berfokus menganalisis atau menafsirkan bahan tertulis berdasarkan konteksnya. Data diambil dari observasi. Hasil analisis menemukan, produk berkualitas baik yang mampu membaca keinginan konsumen dengan didukung desain kemasan yang menarik disertai teknik pemasaran yang tepat mampu menghasilkan keuntungan bagi perusahaan dengan usaha yang efektif, efisien berpengaruh positif bagi seluruh lini perusahaan.

Kata kunci: komunikasi; manajemen periklanan; saham.

\section{Pendahuluan}

Indonesia merupakan negara yang dilintasi garis khatulistiwa, berada di Asia Tenggara dan diapit dua benua Asia dan Australia dan berada di antara Samudra Pasifik dan Samudra Hindia, dilansir melalui laman wikipedia Indonesia adalah negara kepulauan yang terdiri dari 17.504 pulau. Dengan populasi mencapai 270.203.917 jiwa pada tahun 2020, menempati posisi keempat sebagai negara dengan penduduk yang terbesar di dunia serta sebagai negara berpenduduk Muslim terbesar di dunia, dengan penganut lebih dari 230 juta jiwa.

Agama Islam sebagai agama yang paling banyak dianut warga negara Indonesia, agama Islam sendiri merupakan agama yang telah sempurna diturunkannya oleh Allah swt. bagi seluruh umat manusia melalui para utusan-Nya. Agama Islam bukanlah agama baru, namun Islam adalah agama yang diwahyukan oleh Allah SWT. kepada para utusanNya secara berkala. Sejak utusan yang pertama, kemudian disusul utusan-utusan berikutnya sesuai dengan tingkat kebutuhan pikir dan sosial bangsa manusia. Hingga sampailah bangsa manusia kepada kematangan derajat kemanusiaannya dalam segi mentalitas dan pemikiran, sehingga Allah mengutus Nabi Muhammad saw. menjadi khatamul ambia Rasul terakhir yang bertugas untuk memperbaharui serta menyempurnakan dakwah para utusan yang terdahulu (Syaifi, 2019).

Setiap agama tentu memiliki ajaran yang wajib dilaksanakan oleh penganutnya sebagai bentuk ketatan seorang hamba terhadap agama tersebut. Sebagaimana demikian agama Islam memiliki perintah-perintah dan larangan-larangan yang harus senantiasa ditaati oleh umat muslim sebgai bukti keberimanan seorang muslim tersebut.

Beberapa bentuk perintah agama Islam yang wajib dilaksanakan bagi tiap muslim yang mampu melaksanakannya adalah puasa di bulan suci Ramadhan. Melansir dari website Kementrian agama Sumatra Selatan dalam suatu tulisan berjudul Ramadhan dan Pendidikan Umat: Menuju Indonesia yang sejahtera menerangkan bahwa bulan Ramadhan diartikan sebagai panas. Penamaan ini dipilih oleh orang-orang Arab karena pada bulan kesembilan tahun arab tersebut identik dengan padang pasir kerap menjadi 
Muhammad Ilham Kurniawan, Popo Subroto, Maryana, Syahrial Shaddiq, dan Muhammad Zainul.

sangat panas oleh terik matahari. Selain dinamakan bulan yang amat panas Ramadhan juga dikena sebagai Syahr al-Shiyam (bulan puasa wajib), sebab hanya pada bulan Ramadhan umat Muslim diwajibkan melaksanakan puasa selama sebulan penuh dan hanya bulan Ramadhan, satu-satunya, nama bulan yang disebut dalam Alquran. (QS AlBaqarah [2]: 185).

Indonesia sebagai negara nan sarat akan keanekaragaman yang luar biasa baik sumberdaya alam maupun budaya, tak terhindarkan pula keanekaragaman di bidang makanan baik warisan leluhur maupun makanan hasil akulturasi budaya luar. Seperti mi atau bakmi misalnya yang dibawa dan diperkenalkan ke Indonesia oleh kaum pendatang, etnik Tionghoa. Bagi masyarakat Tionghoa mie merupakan makanan populer yang berbentuk seperti tali dan dapat diulur panjang serta dapat dinikmati dengan cara disedot tersebut merupakan lambang keawetan hidup. Berbeda dengan mi atau bakmi mie instan atau mie yang dapat disajikan secara cepat ternyata berasal dari negara Jepang yang dikenal sebagai ramen yang kemudian menjadi mie instan atau instan noodle.

Mie instan merupakan makanan yang mendadak, instan atau siap saji, dapat dijadikan makanan alternatif mengganti makanan pokok sebelum seperti beras, tapioka, dan singkong yang mana makanan pokok tersebut memerlukan waktu yang cukup lama dalam proses penyajian dan konsumsinya. Bagi konsumen yang tidak memiliki waktu cukup untuk menyajikan dan mengkonsumsi makanan pokok seperti biasa, maka mereka akan memilih untuk mengkonsumsi mie instan (Harsanto, 2015).

Sebagai makanan mi instan mendapat nilai positif, baik sebagai makanan utama ataupun pendamping. Meski memerlukan proses memasak, tetapi Mi instan tidak begitu sulit dalam proses pemasakan. Berdasarkan hal tersebut mi instan dapat diartikan, sebagai makna yang mudah didapat, praktis pengolahannya, murah harganya, dan cukup kalori (Harsanto, 2015).

Masyarakat Indonesia pertama kali diperkenalkan dengan mi instan pada tahun 1969, mi instan awalnya mi instan dianggap tidak akan mampu untuk menggeser apa lagi mengganti salah satu bahan makanan pokok. Tetapi seiring berjalannya waktu dengan harga yang cukup ekonomis, penyajian yang mudah dan awet. Menjadikan mi instan berkembang pesat di Indonesia sehingga bermunculan produk-produk mi instan diantaranya adalah Indomie yang mampu mendominasi pasar mi instan dalam dan luar negeri.

Produk pertama yang beredar di Indonesia yang sesuai dengan selera lidah dan disukai masyarakat Indonesia adalah Indomie Kuah dengan Rasa Kaldu Ayam. penjualan produk Indomie mengalami peningkatan yang sangat signifikan di tahun 1982 sebagai tanda dengan peluncuran varian Indomie Kuah Rasa Kari Ayam, disusul dengan peluncuran varian Indomie Mi Goreng pada tahun 1983 sebagai bukti semakin digemari produk mi instan dari Indomie oleh masyarakat Indonesia.

Produk yang baik meskipun memiliki kualitas baik dengan harga bersahabat bagi seluruh lapisan ekonomi tidak akan bisa maksimal tanpa didukung oleh pemasaran yang tepat, guna menunjang hal tersebut diperlukan desain yang tepat untuk diterapkan pada kemasan produk. 
Desain kemasan sebagai dapat dipahami sebagai seluruh kegiatan sejak merancang struktur kemasan dan penentuan grafis guna mendukung tersampaikannya informasi dengan baik melalui kemasan. Dilihat dari segi fungsi, kemasan memiliki dua fungsi utama. Pertama, kemasan produk berfungsi sebagai media yang dapat melindungi dan menjaga produk dari kemungkinan-kemungkinan yang memicu timbulnya kerusakan pada produk seperti sinar matahari, cuaca, terjatuh, tumpukan yang melebihi kapasitas, kuman, binatang dan sebagainya. Kedua, kemasan berfungsi sebagai alat media yang menyampaikan pesan dan informasi tentang produk yang bersangkutan.

Kemasan merupakan elemen yang sangat penting di zaman modern ini, sebab kemasan dapat menjadi alat pemasaran dan berperan sebagai identitas suatu merek dagang (brand). Kemasan juga berperan penting penjual atau pemasar barang dengan sendirinya, terutama saat produk berhadapan dengan pesaing dari poruk sejenis, oleh karenanya kemasan disebut juga sebagai penjual tanpa suara (silent salesman).

Perusahaan yang telah berkembang pesat tentu ingin memperluas dan mempertahankan usaha yang dimiliki. Untuk itu diperlukan sokongan dana dari investor oleh karenanya perusahaan perlu memiliki status initial pubic offering (Penawaran Umum Perdana) agar dapat menjual sahamnya ke publik.

Tanda bukti penyertaan kepemilikan modal pada suatu perusahaan atau dikenal sebagai saham. Secara umum terbagi menjadi dua jenis yaitu saham biasa (common stock) dan saham istimewa (preferred stock). Suatu surat berharga tanda kepemilikan dalam perusahaan yang ikut menanggung resiko apabila perusahaan mengalami kerugian dan mendapatkan keuntungan apabila perusahaan mendapat laba atau keuntungan disebut sebagai saham bias. Suatu surat berharga tanda kepemilikan dalam perusahaan dimana pemegangnya akan diberi pendapatan tetap berbentuk dividen yang diterima perperiode pembagian dividen yang telah tentukan disebut sebagai saham istimewa. Untuk memperoleh keuntungan atau yang dalam konteks manajemen investasi tingkat keuntungan disebut sebagai return merupakan alasan utama investor mengapa ingin berinvestasi pada saham.

Menarik kiranya ketika membahas keterkaitan antara desain suatu kemasan dengan nilai saham perusahaan yang mana pembahasan seperti ini belum menarik minat para peneliti. Sehingga berdasarkan latarbelakang di atas maka penting kiranya dilaksanakan penelitian sederhana untuk mengetahui bagaimana Peran Desain Kemasan Indomie Edisi Ramadhan 2021 Terhadap Nilai Saham PT. Indofood Sukses Makmur Tbk. Periode Februari s/d April 2021.

\section{Metode Penelitian}

Pendekatan penelitian dalam penelitian ini menggunakan pendekatan kualitatif dengan metode analisis deskriptif, penelitian deskriptif dengan memaparkan situasi atau peristiwa. Penelitian ini sendiri termasuk sebagai bagian dari penelitian kepustakaan (library research) di mana dalam pelaksanaan penelitian berfokus untuk menganalisis atau menafsirkan bahan tertulis berdasarkan konteksnya (Mahdi, 2014). 
Muhammad Ilham Kurniawan, Popo Subroto, Maryana, Syahrial Shaddiq, dan Muhammad Zainul.

Sumber data untuk penelitian ini diambil dari observasi, yaitu melakukan pengamatan langsung melalui pengkajian dari buku, jurnal, berita-berita terkait yang dilansir melalui media massa elektronik, maupun sumber lain yang menunjang kelancaran penelitian.

Analisi deskriptif digunakan dalam penelitian ini sebagai alat analisis data, ini merupakan teknik pembahasan dengan pemaparan masalah dengan analisis dan pemberian penjelasan yang dalam terhadap suatu data. Berusaha untuk menyelidiki data, memaparkan, menganalisis dan menjelaskan data merupakan bagian dari teknik analisis deskriptif (Mahdi, 2014).

\section{Hasil dan Pembahasan}

Hasil dan pembahasan berisi hasil-hasil temuan penelitian dan pembahasannya secara ilmiah. Tuliskan temuan-temuan ilmiah (scientific finding) yang diperoleh dari hasil-hasil penelitian yang telah dilakukan tetapi harus ditunjang oleh data-data yang memadai. Temuan ilmiah yang dimaksud di sini adalah bukan data-data hasil penelitian yang diperoleh. Temuan-temuan ilmiah tersebut harus dijelaskan secara saintifik meliputi: Apakah temuan ilmiah yang diperoleh? Mengapa hal itu bisa terjadi? Mengapa trend variabel seperti itu? Semua pertanyaan tersebut harus dijelaskan secara saintifik, tidak hanya deskriptif, bila perlu ditunjang oleh fenomena-fenomena dasar ilmiah yang memadai. Selain itu, harus dijelaskan juga perbandingannya dengan hasil-hasil para peneliti lain yang hampir sama topiknya. Hasil-hasil penelitian dan temuan harus bisa menjawab hipotesis penelitian di bagian pendahuluan.

Berdasarkan data terbaru tertanggal 11 Mei 2020 pada situs Asosiasi Mie Instan Dunia (World Instan Noddles Association) mencatat permintaan global untuk mie instan sepanjang tahun 2019 dunia mengonsumsi mie instan sebanyak 106,420 miliar atau ratarata 291 juta porsi konsumsi mie instan dalam sehari. Selama tahun 2019 Indonesia menduduki peringkat ke 2 dengan konsumsi mie instan sebanyak 12,520 miliar konsumsi mie instan dalam setahun dengan rata-rata perhari sebanyak 34,3 juta porsi perhari.

\section{A. Komunikasi pemasaran}

Komunikasi adalah proses interaksi sosial yang terjadi antara setidaknya dua orang atau lebih yang salah satu darinya mengirimkan sejumlah simbol tertentu kepada yang lain. Komunikasi yang baik akan terjadi ketika kedua belah pihak bisa mengolah simbol yang disampaikan dengan baik. Sedangkan pemasaran merupakan sekumpulan perancangan suatu kegiatan yang saling terkait dalam mengenali keperluan konsumen dan pengembangan, pendistribusian, promosi, dan proses penetapan harga yang tepat untuk sebuah produk dan layanan guna tercapainya kepuasan konsumen terhadap produk dengan tujuan menghasilkan keuntungan bagi produsen seefektif dan efisien mungkin.

Usaha untuk penyebaran informasi, mempengaruhi, membujuk atau peningkatan isi pesan terhadap pasar oleh perusahaan dan produknya agar pasar mau menerima, membeli bahkan loyal terhadap produk yang ditawarkan oleh perusahaan tersebut merupakan kegiatan dari komunikasi pemasaran (Lengkey et al., 2014). Sehingga 
komunikasi pemasaran dapat dipahami sebagai suatu proses pertukaran informasi yang berlangsung secara persuasif hingga terjadinya proses pemasaran yang berjalan lancar dengan sefektif dan efisien mungkin (Rahmani et al., 2020).

\section{B. Pengolahan Informasi}

Segala sesuatu yang dirasakan oleh pancaindera baik yang didengar telinga, dilihat mata atau dicium hidung, adalah bentuk dari stimulus. Stimulus dapat berbentuk apa saja baik produk, iklan, nama suatu merk atau produsen. Akan tetapi semua stimulus tersebut tentu tidak dapat diingat dan disimpan dalam ingatan konsumen secara menyeluruh, hal ini dikarenakan konsumen perlu memproses dan mengolah informasi didalam benaknya.

Proses pengolahan informasi menurut Engel, Blackwell dan Miniard memerlukan lima tahapan yaitu: Pemaparan stimulus agar konsumen dengan pancainderanya menyadari keberadaan stimulus tersebut. Pengelolaan stimulus yang msuk sehingga menimbulkan perhatian, setelahnya konsumen akan memahami atau menginterpretasikan makna stimulus yang didapat. Setelahnya terbentuklah persusasif oleh stimulus terhadap konsumen, kemudia menimbulkan pengalihan makna dan persuasi dari stimulus ke ingatan jangka panjang konsumen (Shinta, 2011).

\section{Periklanan}

Pengarahkan komunikasi persuasif pada konsumen dan masyarakat luas merupakan kegiatan periklanan yang lumrah diterapkan oleh perusahaan. Sebagai bagian dari kehidupan industri modern yang mana kehidupan dunia modern periklanan saat ini menjadi bagian paling penting yang tidak dapat dipisahkan. Penggunaan media bauran oleh penjual dalam menyebarkan informasi persuasif tentang produk, jasa atau pun organisasi dan merupakan alat promosi yang kuat merupakan bentuk dari periklanan itu sendiri. Ia merupakan komunikasi non pribadi dengan memanfaatkan berbagai media yang dapat dibayar oleh perusahaan bisnis, organisasi nirlaba atau individu yang berharap dalam pesan periklanannya dapat memberikan informasi atau membujuk anggotaanggota dari pemirsa tertentu agar tertarik dan menyadari produknya.

Periklanan sendiri memiliki peran sebagai pembangun kesadaran (awareness) masyarakat akan keberadaan suatu produk yang ditawarkan, membantu menambahkan pengetahuan konsumen dan calon konsumen tentang produk yang ditawarkan, sehingga calon konsumen terbujuk untuk membeli dan menggunakan produk tersebut. Iklan dapat dijadikan sebagai identitas diri perusahaan sehingga mampu menjadi berbeda dengan perusahaan yang lainnya (Firmansyah, 2020).

\section{Definisi Kemasan}

Segala kegiatan baik mulai dari merancang dan memproduksi tempat pembungkus produk adalah bentuk dari pengemasan. Kemasan bisa dimaksimalkan pemanfaatannya guna menjadi media pemasaran yang tepat dengan syarat harus terpenuhinya faktor penting yang mendukung fungsi kemasan tersebut antara lain: Faktor 
Muhammad Ilham Kurniawan, Popo Subroto, Maryana, Syahrial Shaddiq, dan Muhammad Zainul.

pengaman, sepatutnya suatu kemasan dapat melindungi produk dari hal-hal yang memungkinan menjadi menyebabkan terjadinya kerusakan pada produk. Faktor ekonomi, penentuan kemasan harus sebisa mungkin menggunakan biaya produksi sefektif dan efisien mungkin. Faktor pendistribusian, kemasan wajib mendukung dan mempermudah proses distribusi dari pabrik ke distributor dan pengecer hingga produk diterima oleh konsumen, mudah saat menyimpan dan memajang perlu juga untuk diperhatikan. Faktor komunikasi, kemasan sebagai media komunikasi tentu harus bisa mencerminkan produk, membentuk citra merek yang positif, dan juga sebagai media promosi produk. Faktor argonomi, kemasan yang baik harus mudah saat dibawa, dipegang, dibuka serta mudah saat diambil isinya. Faktor estetika atau keindahan pada kemasan mencakup daya tarik visual dengan mempertimbangkan pemakaian warna, bentuk dan lainnya. Faktor identitas, kemasan suatu produk harus berbeda dengan kemasan lain, adanya kepemilikan identitas produk yang mudah dikenali dan dibedakan dengan produk lain yang sejenis. Faktor keamanan, perlu diperhatikan bahan pembuat kemasan tidak mencemari produk yang ada didalamnya, tahan air, kedap udara, anti mikroba, mudah dibuka-tutup dan dibuang, tidak menimbulkan kerusakan lingkungan, memenuhi kebutuhan ukuran, bentuk, berat dan lain sebagainya agar sesuai dengan produk yang dikemas (Putri, 2017).

Perancangan dan kegiatan pembuatan tempat, wadah atau bungkus yang untuk digunakan pada suatu produk merupakan proses dari terbentuknya kemasan. Perlunya kemasan didasari oleh keperluan untuk melindungi produk selama dalam proses distribusi hingga sampai dan diterima oleh konsumen. Keperluan untuk memberi kesan yan bersih, produk yang tahan saat terpapar cuaca dan nilai estetik. Keperluan dalam memasarkan produk, pembentukan identitas guna mencegah tertukar dangan produk sejenis dari pihak pesaing.

Selain alasan diatas kemasan turut andil dalam menjaga dan meningkatkan laba perusahaan, dengan kemasan yang yang didesain semenarik mungkin diharapkan mampu mempersusi, memikat dan menarik perhatian konsumen yang menimbulkan rasa percaya untuk memilih produk tersebut (Christine Suharto Cenadi, 2000).

\section{E. Fungsi Kemasan}

Pakar bidang pemasar Hermawan Kartajaya berpendapat dengan adanya teknologi fungsi kemasan kini telah kemasan berubah yang sebelumnya kemasan berfungsi untuk melindungi apa yang dijual, saat ini kemasan menjual apa yang dilindunginya. Kemasan bukan sekedar menjadi pelindung atau wadah bagi produk, melainkan kemasan harus mampu menjual produk yang dikemasnya.

Fungsional kemasan semakin terus berkembang hingga sekarang dimana kemasan berfungsi sebagai media untuk komunikasi produk dengan konsumen. Seperti kemasan produk susu atau makanan bayi yang biasanya tertera nomor telepon bebas pulsa yang dapat dihubungi oleh konsumen baik untuk komplain maupun sebagai pusat informasi segala sesuatu yang berhubungan dengan produk tersebut.

Kemasan memilliki fungsi menjadi media yang mengkomunikasikan citra tertentu dari suatu produk. Seperti produk-produk makanan dari negara Jepang yang mana 
kemasan terlihat begitu menarik bahkan terasa nikmat untuk dilihat daripada rasa dari produknya. Meskipun tidak terdapat tertulis pada kemasan tersebut, akan tetapi kemasannya telah mampu memberikan pesan komunikasi yang kuat tentang citra positif dari produ tersebut.

Kesan yang menegaskan perebedaan dengan produk lain yang sejenis, agar produk tersebut tidak tenggelam oleh produk lain harus tertanam dalam desain suatu kemasan. Sehingga konsumen mudah menangkap dan menerima pesan dan kesan yang ingin disampaikan oleh produsen melalui kemasan meski calon konsumen belum pernah sekalipun merasakan produk tersebut, kemasan menjadi pendukung produk saat mampu berhadapan dengan produk lain terutama produk terdahulu yang telah lama beredar dipasar. Berdasarkan fungsinya yang begitu penting, maka konsep fungsional dalam pengemasan harus bisa melewati seluruh proses pemasaran sejak pembuatan konsep produk hingga ke pemakai akhir (Christine Suharto Cenadi, 2000).

\section{F. Elemen Komunikasi pada Desain Kemasan}

Perencanaan struktur pada kemasan baik dari segi grafis yang berguna untuk menyampaikan informasi produk maupun dari segi fungsi termasuk dari bagian desain kemasan. Ada dua fungsi utama yang harus dimiliki kemasan, yaitu: Sebagai media yang berperan dalam melindungi produk dari segala kemungkinan penyebab terjadinya kerusakan pada produk dan sebagai alat atau media dalam penyampaian informasi tentang produk yang dikemasnya.

Sebagai pemegang elemen penting kemasan berperan menjadi alat untuk pemasaran dan sebagai bagian identitas merek dagang suatu produk. Menjual barang dengan sendirinya dan menjaga eksistensi produk dalam persaingan ketat dengan berbagai produk terutama produk sejenis dari produsen berbeda merupakan peran penting yang harus bisa dimiliki suatu kemasan. Selain itu kemasan secara tidak langsung menjadi penjual tanpa bersuara (silent salesman). Kemasan juga berperan sebagai faktor terakhir dalam mempengaruhi pilihan konsumen sebelum memutuskan pembelian.

Tuntutan sebagai media komunikasi dan informasi, secara verbal dan visual adalah bagian dari tugas kemasan. Komposisi produk baik pada makanan maupun minuman dan sejenisnya, keterangan halal dan masa kadaluarsa produk termasuk bagian dari informasi verbal. Sedang informasi visual meliputi tipografi, warna dan gambar yang disajikan. Pemilihan grafis yang menarik dan indah yang sarat akan muatan informasi sebagai representasi suatu produk yang ditawarkan. Desain grafis pada kemasan maupun label dapat membantu pembentukan kontak pribadi antara produsen dan konsumen yang kemudian menciptakan dampak psikologis tertentu pada konsumen.

Pada sebuah penelitian menemukan bahwa kebanyakan konsumen memerlukan cukup tujuh detik saat menentukan keputusan dalam membeli, hal ini menjadi tugas penting kemasan agar dapat menarik perhatian calon konsumen dalam kurang dari tujuh detik yang terbagi menjadi setengah detik untuk dapat dikenali dan setengah detik selanjutnya kemasan harus membuat produk dicintai pembeli. Berdasarkan hal tersebut 
Muhammad Ilham Kurniawan, Popo Subroto, Maryana, Syahrial Shaddiq, dan Muhammad Zainul.

maka pesan yang akan disampaikan harus instan dan langsung, dengan tetap mampu memikat emosional konsumen (Nugrahani, 2015).

\section{G. Pemasaran Melalui Desain Kemasan}

Banyak aspek yang perlu diperhatikan dalam pemasaran melalui kemasan misalnya aspek estetika dimana terdapat tiga alasan mengapa estetika patut dianggap penting dan perlu diperhatikan: Estetika mampu memberikan pengaruh secara psikologis dan emosional yang kemudia membentuk loyalitas konsumen terhadap produk. Standar penentuan nilai suatu produk dan harga oleh perusahaan tidak luput dipengaruhi oleh estetika yang tersaji pada kemasan. Dengan estetika sebuah produk dapat menjadi berbeda meski berada dalam persaingan merek dan produk yang kian hari semakin ketat.

Selain pertimbangan nilai estetika, suatu desain kemasan perlu menyempurnakan diri dengan memenuhi beberapa kriteria, antara lain: 1. Stands out (menonjol) kemasan harus terlihat lebih menonjol agar dapat mengoptimalkan fungsinya, sebab setiap produk harus mampu bersaing dengan berbagai produk lain yang sejenis, di antara cara agar dapat menonjol kemasan perlu memilih pengguna warna yang cermat dan tepat, sebab konsumen lebih cepat melihat warna daripada melihat tampilan bentuk dan rupa. Warna dapat dilihat lebih dulu meskipun produk berada di tempat penjualan yang jauh dan di dalam barisan produk sejenis. Bahkan dari jarak jauh warna yang terang akan lebih terlihat lebih dulu, karena warna terang dapat memberikan daya tarik tersendirir. 2. Contents (Isi) kemasan yang baik tentu tidak akan ketinggalan dalam penyampaian informasi isi dalam kemasan dan apa yang terkandung dalam produk. 3. Distinctive (Unik) menjadikan desain kemasan terlihat berbeda dengan produk pesaing. 4. Suitable (Sesuai) kesesuaian produk yang dikemas dengan kemasan, selayaknya produk cair yang dikemas dalam botol (Christine Suharto Cenadi, 2000).

\section{H. Saham}

Suatu tanda penyertaan modal pada suatu perseroan terbatas atau yang disebut sebagai saham, kepemilikan saham bagi investor pada suatu perusahaan dapat memberikan keutungan dari hasil dividen, capital gain dan keuntungan nonfinansial lainnya, seperti rasa bangga dan kewenangan dalam memperoleh hak suara yang menentukan arah perjalanan dari perusahaan tersebut.

Sebagai tanda yang membuktikan keikutsertaan dalam kepemilikan modal di suatu perusahaan, saham yang biasa diperdagangkan pada pasar modal dapat dikelompokkan kedalam dua kelompok yaitu saham biasa (common stock) yang berbentuk surat berharga sebagai penanda kepemilikan dalam perusahaan yang menjadikan pemilik saham ikut menanggung resiko kerugian dan keuntungan yang didapat perusahaan. Sedang saham istimewa (preferred stock). merupakan suatu-surat berharga yang menjadi penanda kepemilikan dalam perusahaan di mana pemegangnya akan diberikan pendapatan tetap berbentuk dividen yang dibagi setiap periode pembagian dividen yang telah ditentukan. Tentunya alasan investor berinvestasi pada saham tidak 
lain ingin mendapatkan keuntungan yang disebut return dalam konteks manajemen investasi tingkat keuntungan (Yulia, 2016).

\section{Faktor yang Mempengaruhi Harga Saham}

Proyeksi penerimaan laba di tiap lembar saham saat laba diperoleh, tingkat resiko yang diperoleh dari proyeksi laba, dan proporsi utang perusahaan terhadap ekuitas, serta kebijakan pembagian deviden merupakan menjadi faktor yang dapat mempengaruhi pergerakan nilai atau harga tiap saham. Selain itu faktor lain seperti kegiatan perekonomian pada umumnya, pajak dan keadaan bursa saham turut andil dalam mempengaruhi perubahan harga saham secara eksternal. Selain itu kondisi dari perusahaan, kendala-kendala eksternal, kekuatan penawaran dan permintaan saham di pasar, kemampuan investor dalam menganalisis investasi pada saham turut serta dalam mempengaruhi harga saham. Menurut Sawidji faktor utama yang menjadi penyebab berubahnya harga saham adalah persepsi yang berbeda dari informasi yang dimiliki tiap investor (Mudjiyono, 2012).

\section{J. Nilai Saham PT. Indofood Sukses Makmur Tbk. Periode Februari s/d April 2021}

Berdasarkan situs saham idnfinansial.com dan id.investigasi.com dapat dilihat pergerakan grafik saham PT. Indofood Sukses Makmur Tbk yang terlihat meninggi dibeberapa waktu terutama pada pertengahan Maret dimana pada pertengahan Maret mulai gencar foto kemasan Indomie edisi Ramadhan beredar di media sosial.

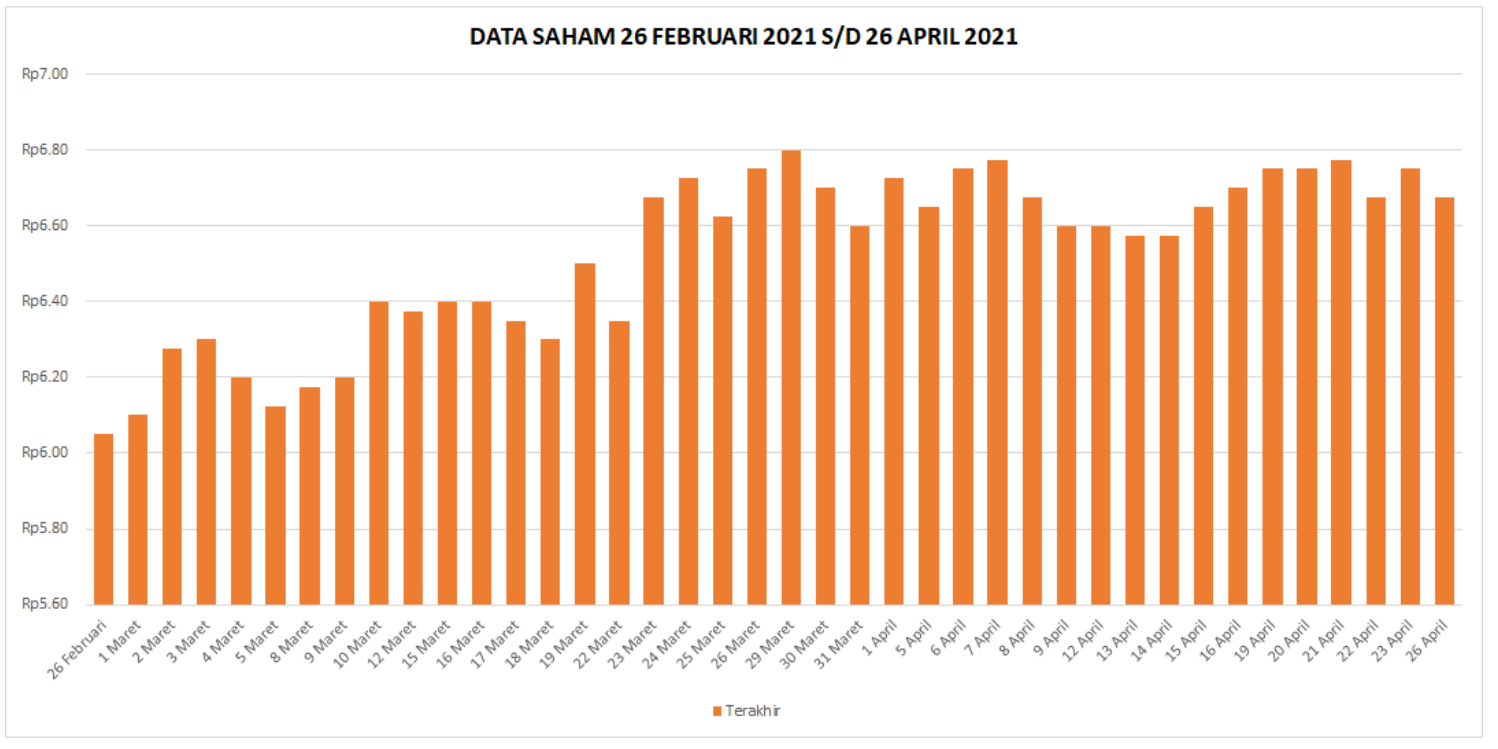

Gambar 1 Nilai Saham PT. Indofood Sukses Makmur Tbk. Periode Februari s/d April 2021

\section{Kesimpulan}

Produk dengan kualitas baik yang mampu membaca keinginan konsumen dengan didukung desain kemasan yang menarik disertai teknik pemasaran yang tepat mampu 
Muhammad Ilham Kurniawan, Popo Subroto, Maryana, Syahrial Shaddiq, dan Muhammad Zainul.

menghasilkan keuntungan bagi perusahaan dengan usaha seefektif dan efisien mungkin. Penelitian ini menemukan bahwa penerapan desain kemasan produk yang tepat mampu mengkomunikasikan produk dengan optimal dan dapat mempengarui psikologi konsumen untuk membeli produk tersebut. Semoga kedepannya banyak penelitian yang mengkaji tentang pengaruh maupun hubungan antara ilmu komunikasi dengan manajemen pemasaran. 
Peran Desain Kemasan Indomie Edisi Ramadhan 2021 Terhadap Nilai Saham PT. Indofood Sukses Makmur TBK. Periode Februari s/d April 2021

\section{Bibliography}

Christine Suharto Cenadi. (2000). Peranan Desain Kemasan Dalam Dunia Pemasaran. Nirmana, 2(2), 92-103.

Firmansyah, M. A. (2020). Buku Komunikasi Pemasaran (T. Q. Media (ed.); 1st ed., Issue June).

Harsanto, P. W. (2015). GAYA HIDUP MODERN DAN IKLAN (Budaya Makan Mi Instan sebagai Identitas). Imaji, 7(1). https://doi.org/10.21831/imaji.v7i1.6645

Lengkey, L. M. E., Kawengian, D., \& Marentek, E. (2014). Peranan Komunikasi Pemasaran Dalam Meningkatkan Minat Pengguna Iklan Di Harian Komentar Manado. Journal Acta Diurna, III(3), 1-14.

Mahdi, A. \& M. (2014). Panduan Penelitian Praktis untuk Menyusus Skripsi, Tesis dan Disertasi. CV Alvabeta.

Mudjiyono. (2012). Investasi Dalam Saham \& Obligasi Dan Meminimalisasi Risiko Sekuritas Pada Pasar Modal Indonesia. Jurnal STIE Semarang, 4(2), 1-18.

Nugrahani, R. (2015). Peran desain grafis pada label dan kemasan produk makanan umkm. Jurnal Imajinasi, IX(2), 127-136.

Putri, B. R. T. (2017). Manajemen Pemasaran. Universitas Udayana.

Rahmani, I., Akbar, R., \& Safarina, F. (2020). Modul Marketing Komunikasi. In Lab. Manajemen Menengah (pp. 1-83). Universitas Gunadarma.

Shinta, A. (2011). Manajemen pemasaran. In Manajemen Pemasaran (I). Universitas Brawijaya Press.

Syaifi, M. (2019). Nilai-Nilai Pendidikan Islam dalam Ibadah Puasa Ramadhan. Tarbawi, 07(02), 1-29.

Yulia. (2016). ANALISIS PENGARUH RASIO LIKUIDITAS TERHADAP RETURN SAHAM (Studi Pada Perusahaan Indeks LQ 45 Yang Terdaftar Di Bursa Efek Indonesia). JURNAL KHATULISTIWA INFORMATIKA, 2(2), 192-204. 